\title{
Description of a minimally invasive technique with a modified instrument for the osteosynthesis of proximal femoral fractures using the standard DHS and case series
}

\section{Osteossíntese de fraturas do fêmur proximal minimamente invasiva com um instrumento modificado usando o DHS padrão: descrição de técnica e série de casos}

Ricardo Ramon Camacho Irigoyen; Rafael de luca de-Lucena ${ }^{2}$ iD ; Jean Klay Santos Machado3; Gabriel Severo da-Silva²; Carlos Roberto Schwartsmann ${ }^{2,4}$; William Dias Belangero5; Leandro de Freitas Spinelli, ${ }^{4,6}$.

\section{A B S T R A C T}

\begin{abstract}
Introduction: the number of hip fractures is estimated to increase from 1.66 million in 1990 to 6.26 million by 2050. Internal fixation is the most common surgical treatment for intertrochanteric fractures. Objectives: the objective of the present research is to describe a minimally invasive technique with a modified instrument for the treatment of stable proximal femoral trochanteric fractures using the standard DHS, classified as Tronzo types 1 and 2 (AO 31A1.2), and presenting a case series. Methods: a case was selected to present the technique. Patients operated by this technique undergo a clinical evaluation and preoperative preparation as routine. The criteria for inclusion in the study were the presence of stable fracture of the proximal femur verified by two hip specialist orthopedists, and operated by the minimally invasive technique with a modified instrument using a standard DHS. Exclusion criteria were cases of patients operated for unstable fractures, and the use of other surgical techniques. A case series of 98 patients was performed and discussed. Results: minimally invasive technique with a modified instrument using the standard DHS device can reduce bleeding, it decreases soft tissue injuries, surgical time, and hospital stay, as any other MIPO procedures. Ninety-eight patients underwent the operation (Tronzo types I and II), 59 female and 39 male, ages from 50 to 85 years old. Immediate post-operative complications were shortening of the lower limb, loss of fracture reduction, and death by clinical complications. Conclusion: the present study describes a minimally invasive surgical technique using a modified instrument to perform proximal femoral osteosynthesis for stable trochanteric fractures, using the standard DHS
\end{abstract}

Keywords: Hip Fractures. Femoral Fractures. Lower Extremity. Minimally Invasive Surgical Procedures.

\section{INTRODUCTION}

$T_{5}^{\mathrm{h}}$ he risk of hip fracture is high, ranging from $40 \%$ to $50 \%$ in women over 60 , and $13 \%$ to $22 \%$ in men. With life expectancy increasing worldwide, and due to these demographic changes, the number of hip fractures is estimated to increase from 1.66 million in 1990 to 6.26 million by $2050^{1,2}$. The estimated annual cost of treating these fractures is enormous and represents a significant burden on any health system?

Internal fixation is the most common surgical treatment for intertrochanteric fractures ${ }^{3}$. The choice between intramedullary or extramedullary devices (plates and screws or dynamic hip screw - DHS) is the most commonly used technique. The immediate benefit of surgical treatment is pain relief, rapid mobilization, accelerated rehabilitation and the maintenance of an independent patient life style ${ }^{4}$.

The fixation of trochanteric fractures is available through the DHS type device and is recognized for its reproducibility, ease of execution and low complication rate. Higher risk of bleeding, soft tissue injury and worse rehabilitation ${ }^{5-7}$ are attributed to classical surgical accesses. Minimally invasive approaches aim to reduce bleeding and decrease local soft tissue injuries. Previous studies have shown benefits of the minimally invasive technique regarding surgical time, hospital stay and blood loss in relation to the conventional technique for the treatment of proximal femoral fractures ${ }^{8,9}$. Ho et al. ${ }^{8}$ also discuss that these benefits are accomplished

1 - Hospital Maradei, Serviço de Ortopedia e Traumatologia - Belém - PA - Brasil 2 - Santa Casa de Misericórdia de Porto Alegre, Serviço de Ortopedia e Traumatologia - Porto Alegre - RS - Brasil 3 - Hospital Porto Dias, Serviço de Ortopedia e Traumatologia - Belém - PA - Brasil 4 - Universidade Federal de Ciências da Saúde de Porto Alegre, Departamento de Clínica Cirúrgica - Porto Alegre - RS - Brasil 5 - Universidade Estadual de Campinas, Departamento de Ortopedia e Traumatologia - Campinas - SP - Brasil 6 - Universidade de Passo Fundo, Programa de Pós-Graduação em Projeto e Processos de Fabricação, Laboratório de Bioengenharia, Biomecânica e Biomateriais - Passo Fundo - RS - Brasil 
without compromising the stability of fracture fixation. Minimally invasive techniques are not new or novel, and are usually performed with special plates and disposals mostly of high costs, being occasionally impracticable for the public heath cares systems. The present study aims to describe a surgical procedure for the osteosynthesis of proximal femoral fractures using a standard DHS with a minimally invasive technique with a modified instrument (135-degree retractable guide).

\section{MATERIAL AND METHODS}

The present study describes a minimally invasive technique using a modified instrument for the treatment of stable proximal femoral trochanteric fractures using a standard DHS, classified as Tronzo types I and II (AO 31A1.2). A case was selected to present the technique. Patients operated by this technique undergo a clinical evaluation and preoperative preparation, as routine. The case presented here has been illustrated for demonstration purposes only. The criteria for inclusion in the study were the presence of stable fracture of the proximal femur verified by two hip specialist orthopedists, and the operation performed by the minimally invasive technique with the proposed modified instrument using a standard DHS. Exclusion criteria were cases of patients operated for unstable fractures, and the use of other surgical techniques. The presented patient was randomly chosen for illustrative purposes of the technique, his identity is kept confidential. The research was previously submitted and approved by the Ethical Committee (No. 22871119300005335).

The classical technique employs open reduction through a $10-15 \mathrm{~cm}$ incision and fixation with the DHS. The minimally invasive technique described herein consists of a shorter lateral access approach (maximum $4 \mathrm{~cm}$ ) and employs the proposed modified instrument using the standard DHS implant, following the same criteria as the traditional technique. A case series of 98 patients was performed and discussed.

\section{DESCRIPTION OF THE TECHNIQUE}

As the traditional technique, the surgical procedure begins with the patient in supine position on a traction table. The fracture is reduced with traction and internal rotation (Figure 1A, 1B). A fluoroscopy assesses the prepositioning of the guide wire over the skin in the fractured hip region, following the cephalo-medullary angle, and the location of the guide wire laterally in the hip is defined (Figure 1C). Then a $4 \mathrm{~cm}$ incision is made observing the guide wire outlet $(1 \mathrm{~cm}$ proximal and $3 \mathrm{~cm}$ distal) (Figure 1D). Skin and subcutaneous tissue, fascia lata and musculature are opened in the stretch. Then the proposed instrument, a disassembled 135-degree boot guide is passed (Figures $1 \mathrm{E}, \mathrm{F}, \mathrm{G}, \mathrm{H}, \mathrm{I})$, mounting the device in the proximal femur (Figures $1 \mathrm{~F}, J)$. The guide wire is introduced (Figure $1 \mathrm{~K}, \mathrm{~L}, \mathrm{M}$ ). Its positioning is evaluated according to the traditional technique, centered on the anteroposterior and lateral in the x-rays views or slightly below and posterior to avoid the cutout (Figure 1L,M).

The new proposed instrument, the 135 degrees positioner is subtly removed by pulling it out and disassembling it, once the wire is positioned as recommended by the literature (Figure $1 \mathrm{~N}$ ). The drilling is performed as usual and the DHS screw is inserted (Figure $10)$, respecting the TAD index. A special instrument, a DHS plate slider (Figure 1P) is used in this step. After inserting the DHS plate in reverse (Figure 1Q), you must rotate it by 180 degrees and hold it (plate) with your finger (Figure 1R,S). The plate slider has a tune that slides the DHS plate, making it easy to insert into the Richards screw (Figure 1P). The screw-like fits into the instrument and facilitates the manipulation in all directions (Figure $1 T, U, V)$. The skin is then pulled down and the cortical screws are inserted (Figure 1W). The fluoroscopy is used to perform the general revision, and then the fascia lata, subcutaneous and skin are closed. Please note the small incision performed with the technique (Figure 1X).

\section{Tips and tricks}

Increased difficulty must be considered for the introduction of the guide wire in patients with soft tissue stiffness, scars, and previous trauma, due to the limitation in handling these structures. It is also important to remember that excess of internal or external rotation of the lower limb can cause tension to the muscles, and consequently make the surgical procedure difficult. Finally, note that the more laterally is the insertion of the 
Richard screw the more hinder is the plate positioning. We suggest leaving 2 to $3 \mathrm{~mm}$ of screw outside the lateral cortex of the femur.
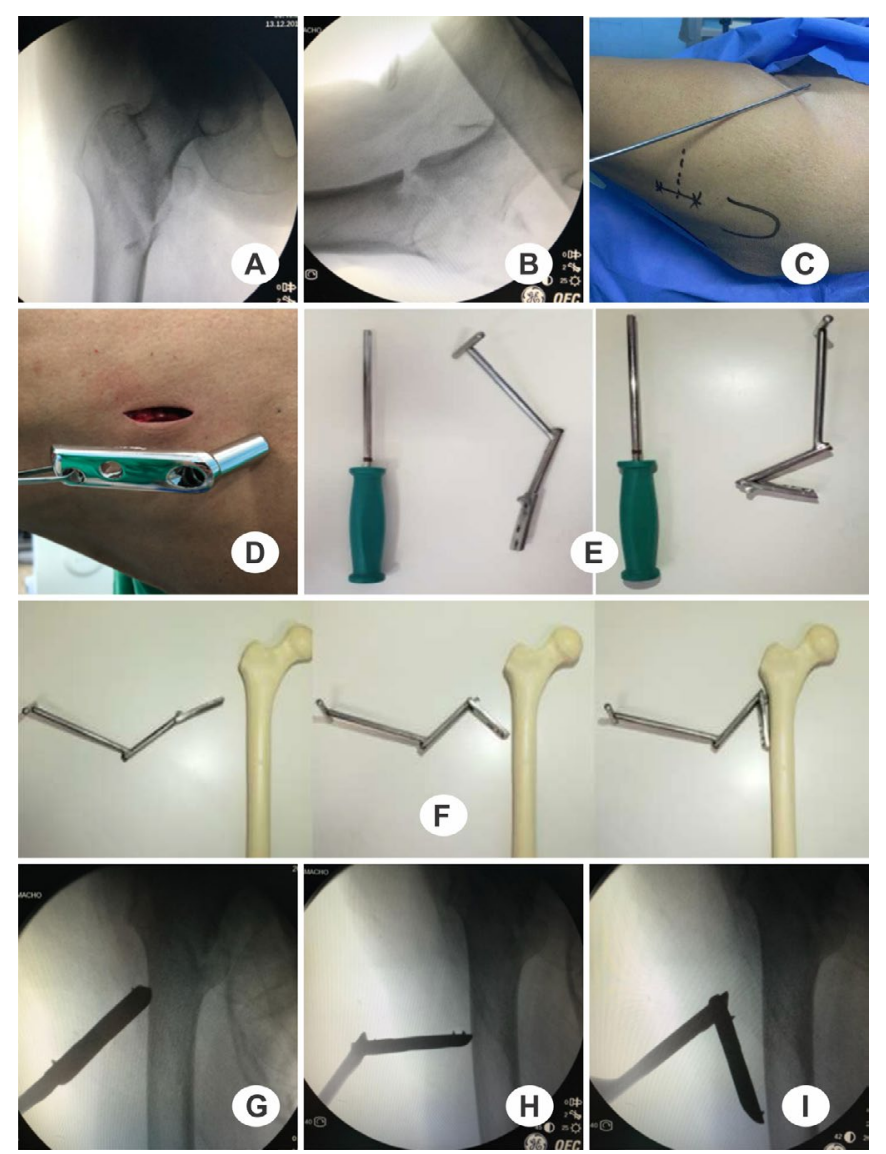

\section{Case series}

Ninety-eight patients underwent this operation (Tronzo types I and II), 59 female (60.2\%) and 39 male $(39.8 \%)$, ages from 50 to 85 years old. Immediate postoperative complications were shortening of the lower limb (5 cases, $5.1 \%$ ), loss of fracture reduction (1 case, $1.02 \%)$, and death by decompensated diabetes (1 case, $1.02 \%)$, prior to hospital discharge. Revisions are usually performed within 2, 4, 8, 12 and 24 weeks.

\section{DISCUSSION}

This study describes a minimally invasive technique with a modified instrument for the treatment of stable transtrochanteric fractures of the proximal femur using an ordinary DHS. Minimally invasive approaches are able to, without compromising the stability of fracture fixation ${ }^{8}$, reduce bleeding, decrease soft tissue injuries, surgical time and hospital stay ${ }^{8,9}$. The latter has prompted our team to perform this study. Surgical techniques for osteosynthesis using minimally invasive plates or MIPO, as they are known, are a relatively recent phenomena and are in constant and growing development. New approaches are being described and new implants and instruments are being introduced to make the procedures easier and more reproducible. An important issue, however, is to understand its principles and apply them correctly. While it is interesting to have the most modern instruments and implants, they are by no means absolutely essential. Conventional implants can be used or adapted for MIPO operations, and the results can be rewarding ${ }^{10}$. In the present study, just adding the thread guide and the implant slips, we present a technique that uses the traditional DHS implant without any modification. This is an important issue in developing countries, considering the population under poverty conditions.

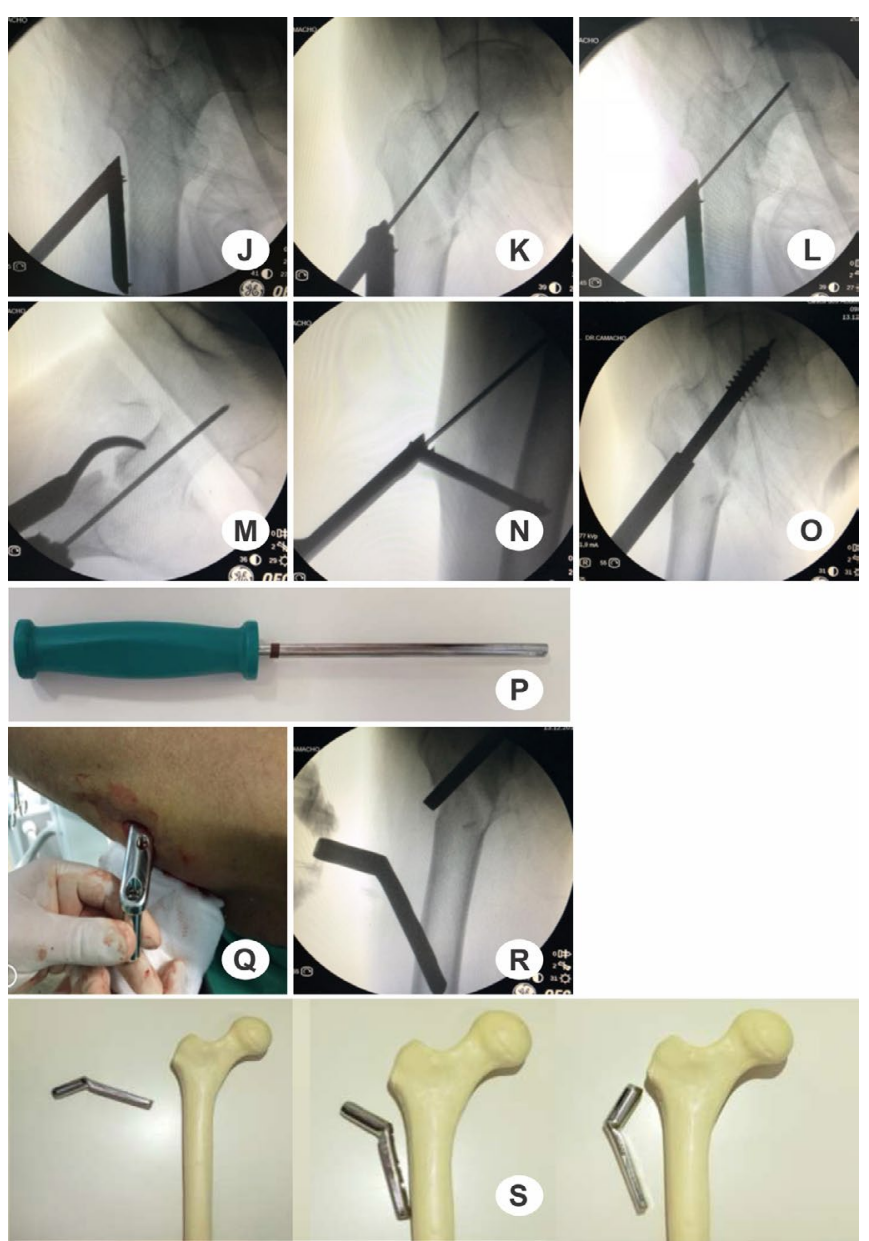




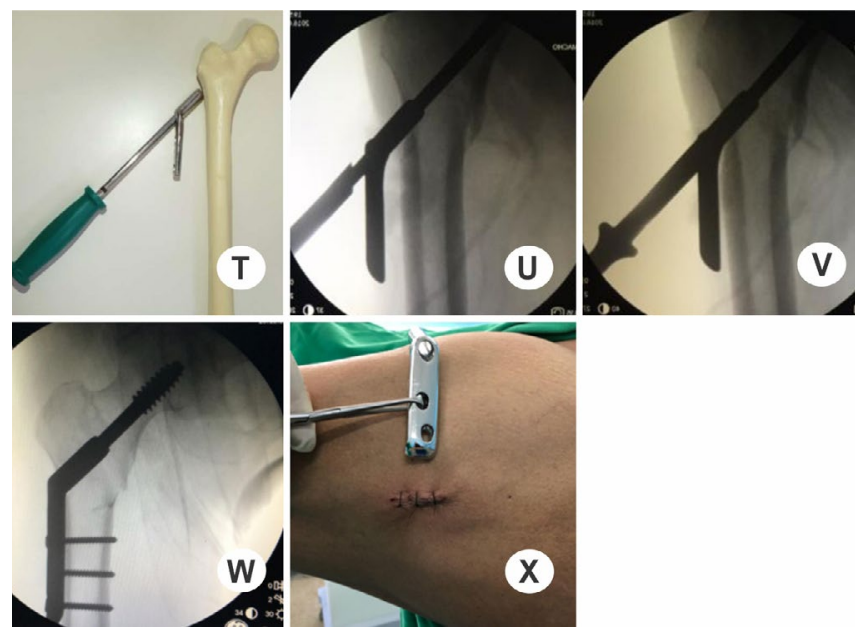

The minimally invasive technique itself is not a new concept in orthopedic surgery. The use of intramedullary nails and percutaneous fixation of fractures using Kirschner screws and wires have been performed with satisfactory results over the years. The plate osteosynthesis application using minimally invasive surgical techniques is the latest technique ${ }^{10}$. Several authors have compared the traditional DHS technique with minimally invasive technique ${ }^{11-16}$. In particular, Cheng et al. ${ }^{13}$ and Mahmood et al. ${ }^{16}$ compared the minimally invasive dynamic hip screw (MIDHS) technique with the conventional DHS technique. The MIDHS technique resulted in less blood loss, shorter hospitalization, and lower pain level when compared with the CDHS technique. Cheng et al. ${ }^{13}$ did not observe significant differences between the groups with regard to postoperative complications and implant position ${ }^{13}$, which was an incentive to the present study. Alobaid et al. ${ }^{17}$ discussed that the minimally invasive technique significantly reduces blood loss and operative time for fixation of intertrochanteric hip fractures without the sacrifice of fixation stability or bone healing. We have observed loss of fracture fixation in just one case (1.02\%) using this technique. Kandel et al. ${ }^{18}$ concluded that the minimally invasive technique using DHS for stable hip fracture has good functional outcome in a cost effective way, with decreased incidence of complications, resulting in great advantage over the conventional method of fixation. This extensive discussion has encouraged us to create a special device to perform the procedure even more easily, in order to take advantage of the minimally invasive procedures.

As with the use of plate in the conventional approach, minimally invasive plate osteosynthesis (MIPO) is also associated with complications. The encountered complications, however, are slightly different from those using the traditional open method. Malrotation, axial misalignment, and limb length discrepancy become more common in MIPO because the fracture is not exposed during the plate reduction and placement. Meanwhile, infection, delayed healing, and therefore failure of the implantation, are less frequent due to the preservation of the fracture site biology that is inherent to the MIPO technique ${ }^{10}$. In the case of the technique presented in this paper, the reduction of the fracture is made in the same way as the open technique, and consequently there is no malrotation or misalignment in this type of fracture. However, we observed shortening of the lower limb in 5 cases (5.1\%), and loss of fracture reduction in one case $(1.02 \%)$.

The authors do recognize that this work has some limitations. Firstly, the authors are not describing the MIPO technique itself, which is not new or novel. Second, the present research performs a description of a technique considering a case series, without patients' randomization, and comparison between groups. However, as we have previously discussed, we have addressed the MIPO technique with a modified instrument using an ordinary DHS, without any modification of the implant. The DHS has a low cost, it can be found in any hospital, which is an important issue in developing countries, considering the population under poverty conditions. It can also be used with a minimally invasive procedure. MIPO technique usually uses high cost implants and instruments, impracticable to public health care systems.

\section{CONCLUSIONS}

The present paper describes a minimally invasive surgical technique with a modified instrument to perform proximal femoral osteosynthesis in stable trochanteric fractures using an ordinary DHS. The proposed surgery can have the benefits of any other MIPO procedures. 


\begin{abstract}
Introdução: estima-se que o número de fraturas de quadril aumente de 1,66 milhão em 1990 para 6,26 milhões em 2050 . A fixação interna é o tratamento cirúrgico mais comumente utilizado para as fraturas intertrocantéricas. Objetivos: o objetivo da presente investigação é descrever uma técnica minimamente invasiva com um instrumento modificado para o tratamento de fraturas trocantéricas femorais proximais estáveis, classificadas como tipos I e ll de Tronzo (AO 31A1.2), usando o DHS padrão, e apresentar uma série de casos. Métodos: foi selecionado um caso aleatório para apresentar a técnica. Os pacientes operados por essa técnica passam por avaliação clínica e preparo pré-operatório de rotina. Os critérios para inclusão no estudo foram a presença de fratura estável do fêmur proximal, verificada por dois ortopedistas especialistas em quadril, e operada pela técnica minimamente invasiva com um instrumento modificado usando um DHS padrão. Os critérios de exclusão foram os casos de pacientes operados por fraturas instáveis e o uso de outras técnicas cirúrgicas. Uma série de casos de 98 pacientes foi realizada e é discutida. Resultados: a técnica minimamente invasiva com o instrumento modificado usando o dispositivo DHS padrão pode reduzir a hemorragia, as lesões dos tecidos moles, o tempo cirúrgico e a estadia hospitalar, tal como quaisquer outros procedimentos de osteossíntese minimamente invasivos. Noventa e oito pacientes foram operados (tipos I e Il de Tronzo), 59 do sexo feminino e 39 do masculino, com idades entre 50 e 85 anos. As complicações pós-operatórias imediatas foram encurtamento do membro inferior, perda da redução da fratura e morte por complicações clínicas. Conclusão: o presente estudo descreve uma técnica cirúrgica minimamente invasiva, utilizando um instrumento modificado para realizar osteossíntese femoral proximal para fraturas trocantéricas estáveis, utilizando o DHS padrão.
\end{abstract}

Palavras chave: Fraturas do Quadril. Fraturas do Fêmur. Extremidade Inferior. Procedimentos Cirúrgicos Minimamente Invasivos.

\section{REFERENCES}

1. Bucholz RW, Heckman JD, Court-Brown CM, Tornetta P, editors. Rockwood and Green's fractures in adults. 7th ed. Philadelphia: Lippincott Williams \& Wilkins; 2010.

2. Dennison E, Mohamed MA, Cooper C. Epidemiology of osteoporosis. Rheum Dis Clin North Am. 2006;32(4):617-29.

3. Kaplan K, Miyamoto R, Levine BR, Egol KA, Zuckerman JD. Surgical management of hip fractures: an evidence-based review of the literature. II: intertrochanteric fractures. J Am Acad Orthop Surg. 2008;16(11):665-73.

4. Fung $W$, Jonsson $A$, Buhren $V$, Bhandari $M$. Classifying intertrochanteric fractures of the proximal femur: does experience matter? Med Princ Pract. 2007;16(3):198-202.

5. Mahmood A, Kalra M, Patralekh MK. Comparison between conventional and minimally invasive dynamic hip screws for fixation of intertrochanteric fractures of the femur. ISRN Orthop. 2013;26:2013:484289.

6. Sawaia RN, Belangero WD. MINUS $®$ System minimally invasive technique for the treatment of trantrochanteric fractures of the femur. Braz J Orthop. 2012;47(1):113-7.

7. Zhang L, Shen J, Yu S, Huang Q, Xie Z. Percutaneous compression plate versus dynamic hip screw for treatment of intertrochanteric hip fractures: a meta-analyse of five randomized controlled trials. ScientificWorldJournal. 2014;2014:512512.

8. Ho M, Garau G, Walley G, Oliva F, Panni AS, Longo UG, et al. Minimally invasive dynamic hip screw for fixation of hip fractures. Int Orthop. 2009;33(2):55560.

9. Hong JY, Suh SW, Park JH, Shin YS, Yoon JR, Yang $\mathrm{JH}$. Comparison of soft-tissue serum markers in stable intertrochanteric fracture: dynamic hip screw versus proximal femoral nail. A preliminary study. Injury. 2011;42(2):204-8.

10. Tong GO, Bavonratanavech S. AO manual of fracture management. Minimally invasive plate osteosynthesis (MIPO). Davos: AO Publishing; 2007.

11. Wong TC, Chiu Y, Tsang WL, Leung WY, Yeung $\mathrm{SH}$. A double-blind, prospective, randomised, controlled clinical trial of minimally invasive dynamic hip screw fixation of intertrochanteric fractures. Injury. 2009;40(4):422-7.

12. Yang E, Qureshi S, Trokhan S, Joseph D. Gotfried percutaneous compression plating compared with sliding hip screw fixation of intertrochanteric hip fractures: a prospective randomized study. J Bone Joint Surg Am. 2011;18;93(10):942-7.

13. Cheng T, Zhang G, Zhang X. Review: Minimally invasive versus conventional dynamic hip screw fixation in elderly patients with intertrochanteric fractures: a systematic review and meta-analysis. Surg Innov. 2011;18(2):99-105.

14. Foulongne $E$, Gilleron M, Roussignol X, Lenoble 
E, Dujardin F. Mini-invasive nail versus DHS to fix pertrochanteric fractures: a case-control study. Orthop Traumatol Surg Res. 2009;95(8):592-8.

15. Zhou Z, Zhang $X$, Tian S, Wu Y. Minimally invasive versus conventional dynamic hip screw for the treatment of intertrochanteric fractures in older patients. Orthopedics. 2012;17;35(2):e244-9.

16. Mahmood A, Kalra M, Patralekh MK. Comparison between conventional and minimally invasive dynamic hip screws for fixation of intertrochanteric fractures of the femur. ISRN Orthop. 2013;2013:484289.

17. Alobaid A, Harvey EJ, Elder GM, Lander P, Guy P, Reindl R. Minimally invasive dynamic hip screw: prospective randomized trial of two techniques of insertion of a standard dynamic fixation device. J Orthop Trauma. 2004;18(4):207-12.

18. Kandel PR, Pathak L, Singh GP, Baral R. Minimal invasive dynamic hip screw fixation for intertrochanteric fractures of femur. Int J of Orth. 2016;3(5):642-6.
Received in: 27/04/2020

Accepted for publication: 15/06/2020

Conflict of interest: no.

Funding source: none.
Mailing address:

Rafael de Luca de-Lucena

E-mail: rfdldl@gmail.com 